\title{
Spektrum dan Kinetika Keadaan Eksitasi Singlet Karotenoid Neurosporene diukur dengan Spektroskopi Serap Pisah Waktu
}

\author{
Ferdy S. Rondonuwu* \\ Program Studi Fisika, Fakultas Sains dan Matematika dan Program Pasca Sarjana Magister Biologi \\ Universitas Kristen Satya Wacana, Jl. Diponegoro 52-60 Salatiga, Indonesia
}

\begin{abstract}
Intisari
Spektrum serap karotenoid neurosporene dengan 9 ikatan rangkap karbon berturutan diukur menggunakan spektroskopi serap pisah waktu. Spektrum diukur menggunakan pasangan laser pulsa ultra cepat masing-masing selebar 120 femtodetik. Didapati bahwa spektrum serap berevolusi sebanyak 3 kali. Kurva kinetik yang dianalisa pada riak gelombang $512 \mathrm{~nm}$ menunjukkan bahwa spektrum serap tersebut turun secara eksponensial dengan 3 konstanta kelajuan yang berbeda. Hasil ini menunjukkan bahwa energi eksitasi karotenoid mengalami deaktivasi melalui kaskade konversi internal dari keadaan $1 \mathrm{~B}_{u}^{+}$ke keadaan dasar $1 \mathrm{~A}_{g}^{-}$(ground state) setelah melewati dua tingkat tenaga intermediat. Hasil ini cocok dengan dugaan bahwa terdapat paling tidak dua tingkat tenaga singlet di antara keadaan dasar dan keadaan eksitasi $1 \mathrm{~B}_{u}^{+}$.
\end{abstract}

KATA KUNCI: karotenoid, spektroskopi serap pisah waktu

\section{PENDAHULUAN}

Karotenoid All-trans pada kompleks pikmen-protein (antena) dari bakteri fotosintesis memiliki fungsi utama yaitu penangkap cahaya. Pada kompleks antena, karotenod terkoordinasi secara unik dengan (bakterio) klorofil membentuk cincin [1]. Konfigurasi cincin karotenoid-bakterioklorofil pada kompleks antena menghasilkan serapan maksimum cahaya matahari pada kisaran riak gelombang $350-900 \mathrm{~nm}$. Kisaran tersebut merupakan optimasi sinergi dari serapan karotenoid pada riak gelombang 420 - $550 \mathrm{~nm}$ dan serapan bakterioklorofil yang memiliki pita serapan sekitar riak gelombang 400, 590 dan $850 \mathrm{~nm}$ [2]. Cahaya yang diserap oleh karotenoid-bakterioklorofil digunakan untuk eksitasi molekul-molekul tersebut dan dikonversi menjadi energi kimia melalui proses fotosintesis.

Sebagai pikmen, karotenoid bertanggung jawab terhadap warna pada daun, buah dan bunga serta beberapa hewan tertentu. Karotenoid beta karoten, misalnya, memberi warna oranye pada jeruk sedangkan karotenoid lycopene memberi warna merah pada tomat. Pakan ternak memanfaatkan karotenoid sebagai sumber nutrisi untuk memberi warna pada daging dan telur. Warna oranye pada daging ikan salmon diberikan oleh karotenoid spirilloxanthin. Warna kuning pada telur ayam dapat diatur dengan jumlah karotenoid beta karoten yang dicampurkan pada pakan. Ditemukan pula bahwa karotenoid dapat mencegah terbentuknya radikal bebas pada tanaman, hewan dan manusia. Untuk memahami, kemampuan luar biasa molekul karotenoid tersebut maka pengetahuan tentang struktur tenaga karotenoid mutlak diperlukan.

*E-MAIL: ferdy_sr@yahoo.com
Karotenoid adalah rantai karbon yang memiliki dua atau lebih simetri independen keadaan elektronik. Berdasarkan simetri $\mathrm{C}_{2 h}$ keadaan elektronik yang dimaksud adalah tingkat aktif optis $1 \mathrm{~B}_{u}^{+}$dan tingkat terlarang optis $2 \mathrm{~A}_{g}^{-}[3,4]$. Tavan dan Schulten [5] menghitung, dengan pendekatan PariserParr-Pople (PPP), bahwa untuk rantai karbon pendek memiliki keadaan-keadaan tenaga singlet $1 \mathrm{~B}_{u}^{+}, 1 \mathrm{~B}_{u}^{-}, 3 \mathrm{~A}_{g}^{-}$dan $2 \mathrm{~A}_{g}^{-}$ dan $1 \mathrm{~A}_{g}^{-}$. Transisi terjadi terjadi di antara sepasang keadaan elektronik yang memiliki tanda Pariser, A, B, g, u, - dan + , berbeda. Konversi internal antara sepasang keadaan elektronik yang memiliki tanda Pariser sama diperbolehkan sedangkan transisi optiknya dilarang. Baru-baru ini Sashima dan kelompoknya [6] melaporkan bahwa terdapat tingkat tenaga dengan karakter $1 \mathrm{~B}_{u}^{-}$di antara tingkat-tingkat tenaga $1 \mathrm{~B}_{u}^{+}$ dan $2 \mathrm{~A}_{g}^{-}$. Tingkat-tingkat tenaga ini didapati dengan cara mengukur Profil-Eksitasi-Raman-Resonansi (RREPs). Untuk karotenoid dengan 9 ikatan rangkap karbon berturutan, tingkat tenaga singlet adalah: $1 \mathrm{~B}_{u}^{+}>1 \mathrm{~B}_{u}^{-}>2 \mathrm{~A}_{g}^{-}>1 \mathrm{~A}_{g}^{-}$. Dengan demikian diduga bahwa deaktivasi energi eksitasi $1 \mathrm{~B}_{u}^{+}$terjadi melalui konversi internal $1 \mathrm{~B}_{u}^{+} \longrightarrow 1 \mathrm{~B}_{u}^{-} \longrightarrow 2 \mathrm{~A}_{g}^{-} \longrightarrow 1 \mathrm{~A}_{g}^{-}$.

Pada penelitian ini, spektroskopi serapan ultra cepat pisah waktu digunakan untuk mendeteksi bentuk spektrum serap tingkat-tingkat eksitasi $1 \mathrm{~B}_{u}^{+}, 1 \mathrm{~B}_{u}^{-}$dan $2 \mathrm{~A}_{g}^{-}$. Spektroskopi ultra cepat dipilih karena waktu hidup tingkat-tingkat eksitasi energi singlet karotenoid berada pada rentang waktu kurang dari 100 ps. Dengan mengukur spektrum serap keadaan eksitasi pada rentang waktu tersebut, diperoleh kurva kinetik dan waktu hidup masing-masing keadaan eksitasi yang dimaksud. Tujuan utama penelitian ini adalah membangun gambaran menyeluruh dan rinci tentang skema tingkat-tingkat tenaga singlet karotenoid dan dinamika eksitasinya. 


\section{EKSPERIMENTAL}

All-trans neurosporene diekstrak dari bakteria fotosintesis Rhodobacter sphaeroides G1C dengan cara seperti yang dijelaskan oleh Fujii dan kelompoknya [7]. Ekstrak tersebut kemudian dilarutkan pada pelarut $\mathrm{n}$-hexane dengan konsentrasi $4 \times 10^{-5} \mathrm{M}$ dan disirkulasikan melalui campuran air-es dan sel sampel yang memiliki ketebalan setara dengan panjang lintasan optis $1 \mathrm{~mm}$. Sampel kemudian dieksitasikan dengan laser yang ditala pada riak gelombang $468 \mathrm{~nm}$.

Spektrum serap pisah waktu dengan resolusi mencapai subpikodetik direkam dengan cara sebagai berikut: Sebuah penguat regeneratif (Spitfire, Spectra Physics) yang menghasilkan laser pulsa $120 \mathrm{fs}$ (800 nm, $1 \mathrm{Khz}, 1 \mathrm{~mJ}$ pulsa-ke-pulsa) dipecah menjadi dua berkas. Berkas pertama dengan dengan daya yang lelatif besar digunakan untuk penguat parametrik optis (OPA-800, Spectra Physics) untuk menghasilkan pulsa laser pemompa dengan riak gelombang $468 \mathrm{~nm}$. Berkas ini diatur sehingga tenaganya mencapai $\backsim 0.4 \mathrm{~mJ}$ atau bersesuaian dengan kerapatan foton pada sel sampel sebesar $\sim 1,2 \mathrm{x}$ $10^{14}$ foton $\mathrm{cm}^{-2}$. Berkas kedua dengan daya yang relatif rendah difokuskan pada lempeng safir setebal $5 \mathrm{~mm}$ untuk menghasilkan cahaya putih supermalar. Berkas cahaya putih supermalar ini selanjutnya digunakan sebagai berkas ukur. Korelasi silang antara berkas pompa dan berkas ukur pulsa-pulsa tersebut didapat sebesar 130 fs yang diukur dengan teknik resonansi signal Kerr [8]. Data spectrum direkam dengan teknik pump-probe yaitu pulsa pemompa ditembakkan ke sampel kemudian spektrum serap diukur menggunakan pulsa cahaya putih supermalar pada kisaran riak gelombang $400-650 \mathrm{~nm}$. Waktu tunda antara pulsa pemompa dan pulsa pengukur diubah mulai dari -0.5 pikodetik sampai 50 pikodetik dengan interval 33 femtodetik. Spektrum yang diperoleh selalu disubtraksikan dengan spekrum serap keadaan dasar karotenoid yang diukur pada waktu yang bersamaan.

\section{HASIL DAN PEMBAHASAN}

Bentuk serapan karotenoid neurosporene pada keadaan dasar ditunjukkan pada Gambar 1. Serapan keadaan dasar ini memiliki struktur vibrasi keadaan $1 \mathrm{~B}_{u}^{+}$dengan puncakpuncak terletak pada riak gelombang $468 \mathrm{~nm}$ yang bersesuaian dengan transisi $1 \mathrm{~B}_{u}^{+}(\mathrm{v}=0) \longleftarrow 1 \mathrm{~A}_{g}^{-}(\mathrm{v}=0), 438 \mathrm{~nm}$ yang bersesuaian dengan transisi $1 \mathrm{~B}_{u}^{+}(\mathrm{v}=1) \longleftarrow 1 \mathrm{~A}_{g}^{-}(\mathrm{v}=$ $0), 414 \mathrm{~nm}$ yang bersesuaian dengan transisi $1 \mathrm{~B}_{u}^{+}(\mathrm{v}=2) \longleftarrow$ $1 \mathrm{~A}_{g}^{-}(\mathrm{v}=0)$ dan seterusnya. Pada percobaan ini karotenoid dipompa dengan laser pada riak gelombang $468 \mathrm{~nm}$ untuk eksitasi $1 \mathrm{~B}_{u}^{+}(\mathrm{v}=0) \longleftarrow 1 \mathrm{~A}_{g}^{-}(\mathrm{v}=0)$. Spektrum serap direkam pada kisaran riak gelombang 400-650 nm dengan waktu tunda $(-0.5)$ - 50 pikodetik. Ketika karotenoid dipompa dari keadaan dasar ke keadaan eksitasi $1 \mathrm{~B}_{u}^{+}$, populasi pada keadaan dasar berkurang secara drastis. Hal ini ditunjukkan dengan munculnya spektrum negatif pada kisaran riak gelombang 400-480 $\mathrm{nm}$. Serapan negatif ini secara perlahan-lahan pulih seiring dengan kembalinya molekul pada keadaan dasar. Hampir bersamaan dengan serapan negatif tadi, muncul serapan positif yang menandakan bahwa serapan transien dari keadaan-

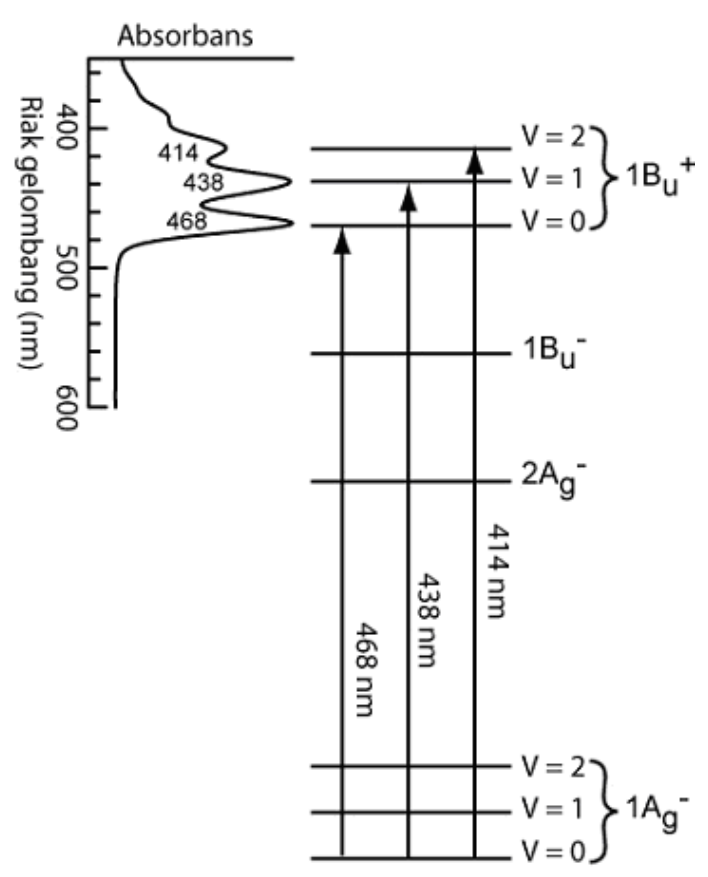

Gambar 1: Tingkat-tingkat tenaga singlet karotenoid neurosporene. Tingkat-tingkat vibrasi ditunjukkan untuk keadaan dasar $1 \mathrm{Ag}$ - dan keadaan eksitasi $1 \mathrm{~B}_{u}^{+}$. Spektrum serap transisi $1 \mathrm{~B}_{u}^{+} \longleftarrow 1 \mathrm{~A}_{g}^{-}$beserta struktur vibrasi elektronik ditampilkan. Garis panah vertikal menunjukkan transisi yang terlibat.

keadaan eksitasi mulai terjadi. Serapan positif ini memiliki puncak yang paling tinggi pada riak gelombang $512 \mathrm{~nm}$. Ketinggian puncak tersebut kemudian turun secara eksponensial. Serapan positif dari tingkat-tingkat transien nampak selalu disertai dengan serapan negatif pada keadaan dasar.

Gambar 2 menunjukkan tiga spektrum khas yaitu pada waktu tunda $0,00,0,50$ dan 7,0 pikodetik. Sesaat setelah molekul dipompa dari keadaan dasar ke keadaan eksitasi, puncak serapan negatif muncul pada riak gelombang 468, 509 dan $540 \mathrm{~nm}$ (Gambar 2a). Puncak negative pada riak gelombang $468 \mathrm{~nm}$ bersesuaian dengan transisi $1 \mathrm{~B}_{u}^{+}(\mathrm{v}=0) \longrightarrow 1 \mathrm{~A}_{g}^{-}$ $(\mathrm{v}=0)$. Serapan negatif pada riak gelombang 509 dan 540 $\mathrm{nm}$ tidak dapat dikorelasikan dengan transisi dari tingkat vibrasi pada $1 \mathrm{~B}_{u}^{+}(\mathrm{v}=1, \mathrm{v}=2)$ ke keadaan dasar $1 \mathrm{~A}_{g}^{-}(\mathrm{v}=0)$ karena transisi ini membutuhkan energi yang relatif besar sehingga puncak-puncaknya harus terletak di sebelah kiri dari puncak serapan transisi $1 \mathrm{~B}_{u}^{+}(\mathrm{v}=0) \longrightarrow 1 \mathrm{~A}_{g}^{-}(\mathrm{v}=0)$. Dengan demikian puncak-puncak tajam pada riak gelombang 509 dan $540 \mathrm{~nm}$ yang muncul sesaat setelah eksitasi diperkirakan terjadi akibat emisi rangsangan yang disebabkan oleh cahaya putih supermalar. Emisi rangsangan ini berhubungan dengan transisi $1 \mathrm{~B}_{u}^{+}(\mathrm{v}=0) \longrightarrow 1 \mathrm{~A}_{g}^{-}(\mathrm{v}=1)$ untuk riak gelombang $509 \mathrm{~nm}$ dan $1 \mathrm{~B}_{u}^{+}(\mathrm{v}=0) \longrightarrow 1 \mathrm{~A}_{g}^{-}(\mathrm{v}=2)$ untuk riak gelombang $540 \mathrm{~nm}$.

Gambar 2b menunjukkan spektrum khas pada waktu tunda 0.50 pikodetik. Terdapat serapan negatif pada riak gelombang kurang dari $480 \mathrm{~nm}$. Serapan negatif ini bersesuaian dengan bleaching keadaan dasar. Pada rentang riak gelombang lebih besar dari $480 \mathrm{~nm}$ terdapat serapan positif dengan pun- 

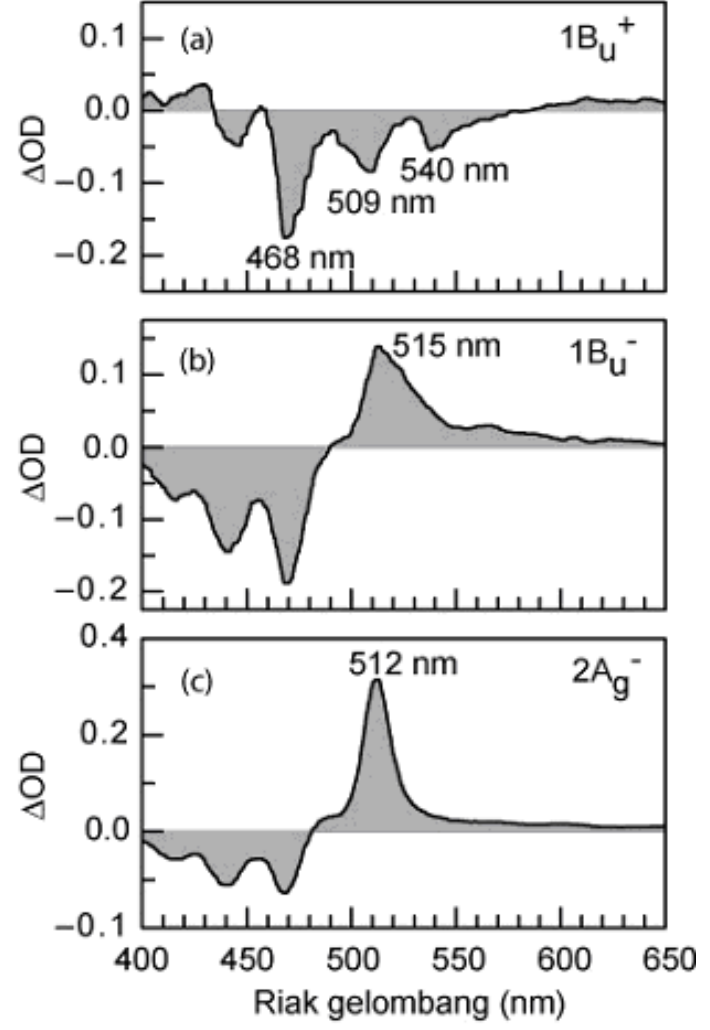

Gambar 2: Spektrum serap khas yang diambil pada waktu tunda (a) 0,00 pikodetik yang bersesuaian dengan tingkat $1 \mathrm{~B}_{u}^{+}$, (b) 0,50 pikodetik yang bersesuaian dengan tingkat $1 B_{u}^{-}$dan (c) 0,70 pikodetik yang bersesuaian dengan tingkat $2 \mathrm{~A}_{g}^{-}$.

cak terletak pada riak gelombang $515 \mathrm{~nm}$. Puncak ini melebar dengan adanya punggung di sebelah kanan. Dari skema tingkat-tingkat tenaga dan urutan kemunculan proses konversi internal, spektrum ini tidak lain adalah serapan khas keadaan $1 \mathrm{~B}_{u}^{-}$Gambar $2 \mathrm{c}$ menunjukkan spektrum khas yang lain yang berbeda dengan dua spektrum sebelumnya. Spektrum negatif muncul akibat bleaching keadaan dasar yang selalu menyertai spektrum serap positif, sedangkan spektrum serap dengan puncak terletak pada riak gelombang $512 \mathrm{~nm}$ tidak lain adalah spketrum serap dari keadaan $2 \mathrm{~A}_{g}^{-}$. Dengan demikian proses deaktivasi keadaan eksitasi $1 \mathrm{~B}_{u}^{+}$terjadi melalui proses internal konversi 3 langkah yaitu $1 \mathrm{~B}_{u}^{+} \longrightarrow 1 \mathrm{~B}_{u}^{-} \longrightarrow 2 \mathrm{~A}_{g}^{-} \longrightarrow$ $1 \mathrm{~A}_{g}^{-}$. Radiasi rangsangan juga didapati muncul dari keadaan aktif optis $1 \mathrm{~B}_{u}^{+}$menuju ke keadaan dasar $1 \mathrm{~A}_{g}^{-}$.

Gambar 3 menunjukkan kurva kinetik yang diplot pada riak gelombang $512 \mathrm{~nm}$. Meskipun riak gelombang ini bersesuaian dengan puncak serapan $2 \mathrm{~A}_{g}^{-}$, namun demikian serapan tingkat-tingkat $1 \mathrm{~B}_{u}^{+}$dan $2 \mathrm{~A}_{q}^{-}$juga masih dicakup pada daerah riak gelombang ini (lihat Gambar 2). Kurva kinetik tersebut kemudian difit dengan multi eksponen menggunakan fungsi respons instrumen Gauss selebar 65 femtodetik (setengah lebar pada setengah maksimum, hwhm). Jumlah eksponesial yang cocok untuk kurva tersebut didapati sebanyak 3 dengan konstanta waktu peluruhan yang muncul secara berurutan masing-masing sebagai berikut: 0,18 pikodetik, 0,52 pikode-

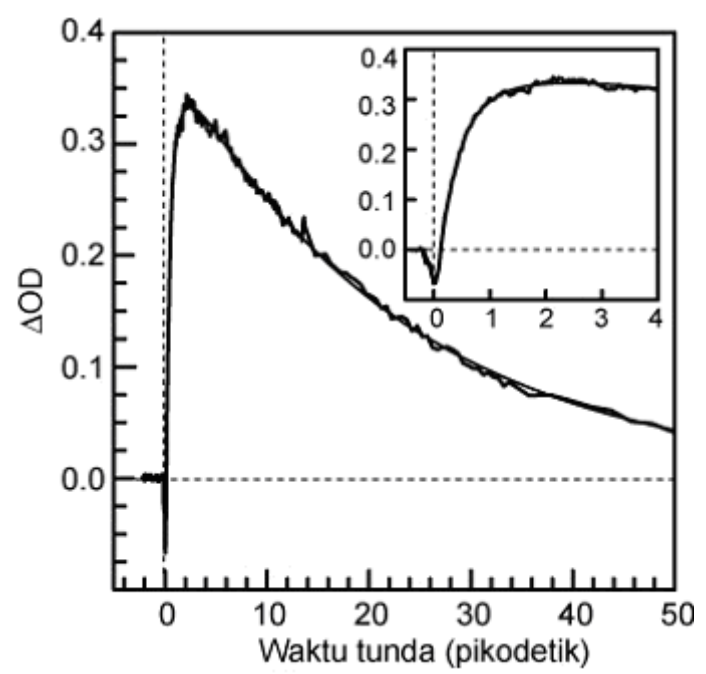

Gambar 3: Kurva kinetik yang diplot pada riak gelombang $512 \mathrm{~nm}$. Kurva fit yang dioptimasi dengan 3 eksponensial ditunjukkan dengan garis mulus. Inset menunjukkan kurva kinetik pada 4 pikodetik pertama.

tik dan 23 pikodetik. Dengan demikian dapat disimpulkan bahwa konstanta waktu peluruhan 0,18 pikodetik berhubungan dengan waktu hidup untuk tingkat tenaga $1 \mathrm{~B}_{u}^{+}, 0,52$ pikodetik untuk tingkat tenaga $1 \mathrm{~B}_{u}^{-}$dan 23 pikodetik untuk tingkat tenaga $2 \mathrm{~A}_{g}^{-}$.

\section{SIMPULAN}

Pada karotenoid neurosporene dengan 9 ikatan rangkap karbon berturutan didapati memiliki struktur tenaga singlet dengan urutan $1 \mathrm{~B}_{u}^{+}>1 \mathrm{~B}_{u}^{-}>2 \mathrm{~A}_{q}^{-}>1 \mathrm{~A}_{g}^{-}$. Hal ini terlihat dari munculnya tiga macam spektrum serap transien dan tiga nilai konstanta waktu peluruhan yang berbeda. Molekul yang dieksitasikan pada tingkat $1 \mathrm{~B}_{u}^{+}$kembali ke keadaan dasar $1 \mathrm{~A}_{g}^{-}$melalui proses konversi internal dengan konstanta waktu peluruhan masing masing 0,18 pikodetik untuk $1 \mathrm{~B}_{u}^{+}, 0,52$ pikodetik untuk $1 \mathrm{~B}_{u}^{-}$dan 23 pikodetik untuk $2 \mathrm{~A}_{g}^{-}$. Hasil ini cocok dengan dugaan bahwa terdapat paling tidak dua keadaan singlet di antara keadaan dasar dan keadaan eksitasi $1 \mathrm{~B}_{u}^{+}$seperti yang diprediksi secara teoritis oleh Tavan dan Schulten melalui metode perhitungan Pariser-Parr-Pople Multi-Reference-Double-excitation Configuration-Interaction (PPP-MRD-CI).

\section{Ucapan Terima Kasih}

Penelitian ini sebagian dilakukan di School of Science, Kwansei Gakuin University, Japan. Penulis mengucapkan terima kasih kepada Prof. Yasushi Koyama atas kesempatan yang diberikan untuk menggunakan fasilitas riset serta diskusi-diskusi yang menarik. 
[1] Koepke J., Hu X., Muenke C., Schulten K., Michel H., Structure 4, 581-597, (1996).

[2] Rondonuwu F. S., Watanabe Y., Fujii R., Koyama Y., Chem. Phys. Lett., 376, 292-301, (2003).

[3] Pariser R., J. Chem. Phys., 24, 250-268, (1956).

[4] Calis P. R., J. Chem. Phys., 78, 16-22, (1983).

[5] Tavan P., Schulten K., Phys. Rev. B, 36, 4337-4358, (1987).
[6] Sashima T., Nagae H., Kuki M., Koyama Y., Chem. Phys. Lett., 299, 187-194, (1999).

[7] Fujii R., Onaka K., Kuki M., Koyama Y., Watanabe Y., Chem. Phys. Lett., 288, 847-853, (1998).

[8] Yamaguchi S., Hamaguchi H.,J. Chem. Phys., 109, 13971408,(1998). 